KATARZYNA KOWALSKA

Uniwersytet Pedagogiczny, Kraków, Polska

\title{
Nowoczesny kanal dystrybucji. Współczesne standardy i strategie rozwoju
}

\section{Modern Channel of Distribution. Contemporary Standards and Development Strategies}

\begin{abstract}
Streszczenie: Artykuł dotyczy konkurencji w handlu detalicznym; roli i znaczenia nowoczesnych strategii marketingowych w procesie konkurowania.

W artykule omówiono podstawowe strategie nowoczesnego handlu w Polsce: politykę niskich cen, lokalizację nowoczesnego handlu w centrach handlowych, rozwój marek prywatnych, koncentracji w handlu.
\end{abstract}

\begin{abstract}
The article concerns competition in retailing as well as the role and significance of modern marketing strategies in the process of competition. Basic strategies of modern trade in Poland: low-prices policy, location of modern trade in shopping centers, private brands developing, concentration of the trade, are discussed in this paper.
\end{abstract}

Słowa kluczowe: konkurencja; marka własna; nowoczesny kanał dystrybucji; polityka cenowa; strategie marketingowe

Key words: competition; marketing strategies; modern channel of distribution; pricing policy; private label

\section{WSTĘP}

Nowoczesny kanał dystrybucji (NKD) obejmuje grupę sklepów wielkopowierzchniowych, do których można zaliczyć hiper-, supermarkety i sklepy dyskontowe. Niespecjalistyczne sklepy wielkopowierzchniowe są podmiotami przede wszystkim branży FMCG (skrót od ang. Fast Moving Consumer Goods), co w praktyce oznacza produkty szybkorotujące, codziennego użytku. Należą do nich przede wszystkim artykuły spożywcze, kosmetyki i chemia gospodarcza. W Polsce operatorami tych obiektów są w przeważającej części 
zachodnioeuropejskie korporacje handlowe, a ich początek funkcjonowania na krajowym rynku odnotowano w latach 90. ubiegłego wieku.

Według danych AC Nielsen, przy wyborze sklepu w Polsce najważniejszą rolę pełnią następujące czynniki (według kolejności): lokalizacja, produkty dobrej jakości i po niskiej cenie, szeroka oferta asortymentowa, atrakcyjne promocje, nowoczesność, przejrzystość i wygoda korzystania ze sklepu oraz fachowa i przyjazna obsługa (AC Nielsen, 2007: 3839). Atrakcyjność nowoczesnego handlu dla klientów wynika właśnie z dostosowania strategii działania omawianych podmiotów do potrzeb współczesnego klienta.

$\mathrm{Z}$ badań wynika, że Polska jest jednym z najpopularniejszych rynków w Europie Środkowo-Wschodniej dla międzynarodowych sieci handlowych. Według prognoz firmy doradczej CB Richard Ellis 33\% z 212 wiodących międzynarodowych sieci handlowych planuje otworzyć w Polsce nowe sklepy (Kłosiewicz-Górecka, 2011: 139). O takim zainteresowaniu naszym krajem decyduje rozwijający się rynek wewnętrzny i skłonność do zakupów, a także stosunkowo duży udział ludzi młodych, którzy preferują nowoczesny kanał dystrybucji (Kłosiewicz-Górecka, 2011).

W ostatnich latach rozwijają się zjawiska, które prawdopodobnie w dalszej perspektywie będą głównymi obszarami inwestycji zagranicznych w strefie handlu. Są to przede wszystkim (Kłosiewicz-Górecka, 2011: 138):

- silny rozwój sklepów dyskontowych;

- pogłębione inwestycje w marki handlowe i wzmocnienie relacji z partnerami biznesowymi i klientami;

- lokalizacja placówek w centrach handlowych i modernizacja obiektów handlu detalicznego;

- fuzje i przejęcia istniejących sieci handlowych;

- inwestowanie w tzw. obiekty kompaktowe;

- modernizacja obiektów handlu detalicznego;

- inwestycje w technologie informacyjne;

- inwestowanie w e-handel.

Celem artykułu jest analiza wybranych (kluczowych) strategii działania w handlu nowoczesnym w Polsce. Szczególna uwaga zostanie zwrócona na działania ukierunkowane na strategie niskich cen, a dokładnie na rozwój sklepów dyskontowych, inwestycje w centra handlowe, działania konsolidacyjne i tzw. inwestycje miękkie - marki handlowe.

Hipotezą pracy jest stwierdzenie, że wdrażane przez operatorów NKD działania marketingowe stają się warunkiem funkcjonowania w handlu detalicznym, przetrwania i rozwoju przedsiębiorstwa w dłuższej perspektywie czasowej.

Obserwacja działań operatorów NKD na krajowym rynku pozwala wyodrębnić kluczowe narzędzia konkurencji z obszaru marketingowego, które są istotne także z perspektywy kształtowania korzystnego wizerunku i konkurencji tych sieci w Polsce. Są nimi przede wszystkim: polityka niskich cen, rozwój własnych marek handlowych i lokalizacja tych jednostek w centrach handlowych najnowszej generacji. 


\section{PolityKa NISKICH CEN I INWESTYCJE W SKLEPY DYSKONTOWE}

Najbardziej czytelnym i oczywistym przejawem konkurencji cenowej w NKD są liczne promocje handlowe (redukcja ceny, kupony, karty klienta itp.) oferowane klientom sklepów wielkopowierzchniowych. Obok tych praktyk odnotowuje się dynamiczny rozwój sklepów dyskontowych, które funkcjonują według strategii niskich cen.

W kontekście rosnącego popytu na tanie artykuły żywnościowe pozycjonowanie cenowe sieci dyskontowych na tle super- i hipermarketów jest dla klientów znacznie bardziej wyraziste i czytelne - niska cena w sklepach dyskontowych dotyczy bowiem wszystkich produktów lub znacznej ich części, w odróżnieniu od pozostałych form nowoczesnego handlu. Na uwagę zasługuje również fakt, że lokalizacja omawianych sklepów stanowi dodatkowy atut dla polskiego klienta, który ceni sobie możliwość robienia zakupów w pobliżu miejsca zamieszkania.

W Polsce cztery kluczowe sieci dyskontowe: Biedronka, Lidl, Netto i Aldi, posiadają blisko trzy tysiące placówek (od 2007 do 2012 r. liczba placówek trzech wiodących sieci dyskontowych co najmniej się podwoiła), a w 2011 r. ich łączne przychody przekroczyły 33 mld zł, co przekłada się na ponad 20\% wzrost rok do roku (Kubacka, 2012: 3).

W ciągu ostatnich pięciu lat liczba dyskontów w Polsce wzrosła o 75\%, a ich przychody o $150 \%$, podczas gdy cały rynek spożywczy zyskał w porównywalnym okresie zaledwie jedną czwartą swojej wartości, co obrazuje tempo, w jakim omawiane sieci zdobyły krajowy rynek i przychylność polskiego klienta (Kubacka, 2012: 3).

Tak silna ekspansja pozwoliła na podwojenie udziałów segmentu dyskontowego w Polsce i wyprzedzenie pozostałych form NKD. Obecnie jeden sklep dyskontowy obsługuje jedynie 13 tys. mieszkańców w porównaniu do 23 tys. odnotowanych pięć lat temu, czyli na milion Polaków przypada ok. 75 sklepów dyskontowych, podczas gdy w 2007 r. przypadały jedynie 43 takie obiekty (Kubacka, 2012: 3).

Ten sukces rynkowy sieci detalicznych, oparty przede wszystkim na wyraźnym pozycjonowaniu cenowym, wywołał kontrstrategie sieci super- i hipermarketów, polegające na lansowaniu nowej koncepcji dyskontowej, będącej mutacją tradycyjnej formuły tych obiektów. Na przykład w sieciach supermarketów E.Leclerc, Champion i hipermarketów dyskontowych Kaufland asortyment uległ zawężeniu, a pozycjonowanie cenowe stało się bardziej wyraźne w porównaniu do tradycyjnych koncepcji tych sklepów (Domański, 2005: 17).

Realizacja strategii niskich cen w handlu nowoczesnym opiera się przede wszystkim na poszukiwaniu możliwości obniżania globalnych kosztów działalności sieci handlowych. Dążenie sieci do pełniejszej kontroli rynku, a w szczególności do kontroli źródeł zaopatrzenia, skłania omawiane firmy do coraz szerszego stosowania różnych form kooperacji (grupy zakupowe) i integracji pionowej. Rosnąca współzależność sieci handlowych i producentów (powiązania pionowe) przejawia się w rosnących inwestycjach omawianych firm w nowoczesne systemy logistyki oraz pozyskiwania informacji. Strategiczność tych obszarów dla zdobywania silnej pozycji na rynku wskazuje na konieczność budowania trwałych relacji z producentami i dostawcami poszczególnych systemów. Ma to szczególne znaczenie 
z perspektywy optymalizacji całkowitych kosztów przepływu produktu, ale również dla pozycjonowania sieci na rynku.

\section{ROZWÓJ MAREK WŁASNYCH W NKD}

Coraz szersze stosowanie strategii integracji pionowej wynika również ze wzrostu roli marki własnej (private labels) w handlu detalicznym. W tym przypadku integracja stwarza w NKD możliwość efektywnego posługiwania się zarówno instrumentami cenowymi, jak również polityką różnicowania oferowanych produktów. Jest to szczególnie ważne w warunkach, w których sukces rynkowy firm handlowych trudno budować, wyłącznie wykorzystując przewagę kosztową.

Pod pojęciem marki należy rozumieć:

kombinację produktu fizycznego, nazwy marki, opakowania, reklamy oraz towarzyszących im działań z zakresu dystrybucji i ceny, kombinację, która odróżniając danego marketera od ofert konkurencyjnych, dostarcza konsumentowi wyróżniających korzyści funkcjonalnych i/lub symbolicznych, dzięki czemu tworzy lojalne grono nabywców i umożliwia tym samym osiągnięcie wiodącej pozycji na rynku (Krall, 2001: 12).

Jako kryterium podziału marek dóbr i usług w literaturze przedmiotu wykorzystuje się prawo własności marki i sposób dystrybucji towarów oznaczonych daną marką (Richardson, Dick, Jain, 1994: 28). I tak marka handlowa, zgodnie z definicją agencji AC Nielsen, należy do przedsiębiorstwa handlu detalicznego lub hurtowego i dotyczy produktów sprzedawanych wyłącznie przez tę firmę lub pod jej bezpośrednią kontrolą (Domański, 2001: 123-129).

Początkowo główną przyczyną rozwoju marek handlowych była nasilająca się dysproporcja w układzie sił pomiędzy producentami a sieciami detalicznymi. Marki własne stały się narzędziem walki handlu wielkopowierzchniowego o kontrolę nad kanałem dystrybucji. Pierwsze działania podejmowane w tym zakresie przez sieć Carrefour miały na celu podważenie istoty marki producenta (tzw. produkty wolne), a późniejsze osłabiały silną pozycję marek poszczególnych producentów (imitacja marki lidera). Obecnie koncepcja marek handlowych jest istotnym narzędziem pozycjonowania oferty sieci, tworzenia jej wizerunku i odróżniania się od konkurencji.

Kluczowe wyzwanie dla poszczególnych sieci detalicznych nie ogranicza się dziś do samej kwestii wprowadzenia marki własnej, lecz obejmuje także określenie jej zakresu, rodzaju produktów objętych tą marką i wskazaniu na typ marki, jaką dana sieć powinna rozwijać (Domański, 2001: 118).

Konieczność posiadania przez sieci handlowe marki własnej wynika z silnej konkurencji na rynku i wiąże się ze względami stricte ekonomicznymi. Atrakcyjność marek własnych dla ich detalicznych właścicieli wynika przede wszystkim z wyższej marży zysku. Według źródeł brytyjskich marża detalisty ze sprzedaży marki własnej jest około 5 punktów procentowych wyższa od marży na porównywalnej marce producenta. Z kolei według danych amerykańskich ta różnica wynosi aż 20-30 punktów procentowych (Krall, 2001: 269-270). 
Osiąganą w ten sposób nadwyżkę dochodów przedsiębiorstwo handlowe może wykorzystać na przykład na obniżkę ceny sprzedaży wybranych produktów.

Dodatkowo marki handlowe gwarantują poprawę konkurencyjności oferty i zwiększenie możliwości negocjacyjnych z poszczególnymi dostawcami. Posiadanie silnej marki własnej umożliwia zagranicznym korporacjom wywieranie większej presji negocjacyjnej wobec producentów wyrobów markowych i w rezultacie uzyskiwanie korzystniejszych warunków transakcji. Silna marka handlowa stwarza realne zagrożenie wycofaniem przez detalistę marki producenta (niebezpieczeństwo jest tym większe, im słabsza jest marka producenta) ze sklepów sieci. Zależność producentów od firm handlowych wynika również z podwójnej funkcji, jaką często pełnią wobec omawianych podmiotów, mianowicie: funkcji dostawcy własnych marek do sieci, jak również funkcji producenta marek handlowych dla tych korporacji. Pozycja producenta jest bardziej zagrożona, jeżeli w znacznym stopniu kontraktuje on u odbiorcy zamówienia na markę handlową (angażuje swoje moce produkcyjne na rzecz określonej sieci). Oczywiście sytuacja taka może również działać na niekorzyść korporacji handlowej.

Atrakcyjność oferty rynkowej zagranicznych sieci detalicznych wynika z dwóch kluczowych obszarów konkurencyjności firmy: różnicowania oferty rynkowej i realizowania polityki niskich cen. Sklepy detaliczne, oferując wiele produktów oznaczonych marką własną (szczególnie jeżeli marka własna rodziny produktów nie jest tożsama z marką sieci), tworzą wrażenie silnie zróżnicowanej oferty rynkowej. Dodatkowym atutem takiej oferty jest znaczna różnica w cenie grupy produktów marki handlowej w stosunku do marek producentów, co w praktyce wspiera pozycjonowanie tych sieci jako sojuszników interesów przeciętnego konsumenta (Domański, 2005: 59).

W Polsce, w przeciwieństwie do krajów o wysokim stopniu koncentracji handlu detalicznego (Niemiec, Wielkiej Brytanii, Holandii, Belgii, Francji, Danii i Szwajcarii), produkty oznaczone marką własną są znacznie mniej popularne wśród konsumentów, gdyż są one kojarzone przede wszystkim z produktami tanimi i niższej jakości (Private labels in Poland: buying ad half price, 2009).

Niewielki udział tych marek na krajowym rynku wynika przede wszystkim z małej koncentracji handlu detalicznego i dominującego udziału produktów marki własnej w segmencie ekonomicznym (tzw. produkty pierwszej ceny). Równocześnie można zaobserwować, że marki własne zagranicznych sieci handlowych stają się w Polsce coraz bardziej powszechne. Więcej firm detalicznych inwestuje w nowe marki skierowane do bardziej wymagających klientów, o wyższej jakości i w ciekawszych opakowaniach. Coraz częściej marki te nie są wyłącznie kopiami produktów markowych, ale oferują nowe, niedostępne na rynku rozwiązania (Private labels get sophisticated, 2009).

Badania w zakresie marek własnych w Polsce dowodzą, iż istnieją segmenty o sporym potencjale dla tych marek oraz te zarezerwowane dla marek producenckich. Wynika $\mathrm{z}$ nich, że private labels mają niewielkie szanse sukcesu w kategoriach opierających się na smaku (np. kawa, wędliny, czekolada). Respondenci natomiast deklarowali, że chętnie sięgają po markę własną, kupując produkty z kategorii chemii gospodarczej. W kategoriach 
spożywczych omawiane marki są akceptowane w przypadku produktów podstawowych np. makaron, ryż, kasza (Twardzik, 2012: 2-3).

Przenoszenie na polski rynek rozwiązań wypracowanych wcześniej na rynkach Europy Zachodniej poprzedzane jest oceną pozycji danej sieci na rynku i jej akceptacją przez konsumentów, jak również warunkami do kształtowania korzystnych relacji z dostawcami produktów wyższej jakości. Można zatem wnioskować, że stopniowe różnicowanie strategii marki własnej, stosowane przez międzynarodowe korporacje handlowe na naszym rynku, świadczy o rosnącej sile przetargowej omawianych firm w kanale dystrybucji i pewnej dojrzałości polskiego rynku do transferu tego typu strategii.

Podstawowa rola marki własnej w rozwoju sieci detalicznych nie wynika jedynie z funkcji, jaką marki handlowe pełnią względem polityki cenowej i asortymentowej, ale jest związana również z bardzo ważnym trendem w handlu detalicznym, tzw. rozmywaniem formatów sklepów (np. Tesco w trzech formatach pod tym samym szyldem). Na skutek takich praktyk coraz większą rolę odgrywa marka sklepu, w tym zakresie właśnie istotne znaczenie mają produkty marki własnej. Produkty handlowe, odpowiednio dopasowane do wymogów klientów danej firmy, stanowią swego rodzaju wartość dodaną, która zapewnia lojalność tych klientów i pomaga w tworzeniu korzystnego wizerunku całej sieci.

\section{LOKALIZACJA NKD w CENTRACH HANDLOWYCH NAJNOWSZEJ GENERACJI}

Duże znaczenie dla wizerunku sklepów NKD i ich siły rynkowej ma również lokalizacja tych obiektów w centrach handlowych najnowszej generacji. Korzyści z funkcjonowania sklepów detalicznych na terenie nowoczesnych ośrodków handlowych wynikają z nowej jakości tych centrów, oferowanej najemcom i potencjalnym klientom. Nowa jakość tych obiektów związana jest przede wszystkim z atutami oferty nowoczesnego centrum i jego miejscem lokalizacji w przestrzeni miejskiej.

Atrakcyjność nowoczesnych centrów handlowych polega na nagromadzeniu w jednym miejscu bardzo dużej i silnie zróżnicowanej oferty handlowo-usługowej (w tym rozrywkowo-rekreacyjnej), a także stworzeniu dla tej oferty doskonalszej przestrzeni architektoniczno-urbanistycznej. W porównaniu z tradycyjnym hipermarketem czy z niewielką galerią handlową współczesne centra mają za zadanie stwarzać klientom znacznie większy wybór produktów i lepsze możliwości spędzania wolnego czasu. Zmianie ulega również klimat przestrzeni centrów. Wdrażane rozwiązania architektoniczne stanowią próbę łączenia walorów z przeszłości (np. mury ceglane, XIX-wieczne konstrukcje metalowe) z nowoczesnymi elementami. Takie podejście, według firm zarządzających dużymi centrami, gwarantuje projektowi tożsamość i uwiarygodnienie całego przedsięwzięcia (Domański, 2005: 171).

Głównym beneficjentem innowacyjnej formy współczesnych centrów handlowych są sklepy NKD, przede wszystkim jednak hipermarkety. Silna współzależność obu form handlu przejawia się przede wszystkim w wielkości powierzchni wynajmowanej przez operatorów 
hipermarketów (kluczowi najemcy) ${ }^{1}$, dominujących udziałach w strukturze sprzedaży danego centrum i skali korzyści osiąganych przez obie strony kontraktu.

Drugim istotnym wyróżnikiem centrów handlowych nowej generacji jest lokalizacja tych obiektów w ścisłych centrach miast. Proces ten jest związany z rewitalizacją centralnych przestrzeni miejskich ${ }^{2}$ i obiektów industrialnych. Zarządy miast, dążąc do ożywienia „umarłych” obszarów miejskich, przyciągają inwestycje o charakterze handlowo-usługowym. Wkomponowanie projektów rewitalizacji w przedsięwzięcia wielofunkcyjne w postaci centrów handlowo-rozrywkowych oznacza w praktyce ich powrót do ścisłej tkanki miejskiej. W nowoczesnej koncepcji miasta handel wielkopowierzchniowy zajmuje główne miejsce. W sensie geograficznym nie ogranicza się jedynie do rynku lokalnego, ale obejmuje swoim zasięgiem często rynek regionalny. Większy zasięg oddziaływania sieci detaliczne zawdzięczają lokalizacji swych sklepów w ośrodkach handlowych, które w warunkach polskich mają zazwyczaj charakter centrów regionalnych (powierzchnia powyżej 40 tys. m kw). Lokalizacja NKD w ścisłych centrach miast oznacza również zaostrzenie konkurencji w handlu detalicznym na tych obszarach.

Proces ten należy traktować jako zjawisko długotrwałe i zyskujące na sile. Świadczy o tym początkowa faza wzrostu centrów handlowych na polskim rynku i faza dojrzałości cyklu życia tej formy handlu w Europie Zachodniej. Silny rozwój centrów handlowych w Polsce potwierdzają dwie najbardziej dynamiczne firmy specjalizujące się w zarządzaniu tymi obiektami: francuska grupy Apsys i niemiecka ECE. Obie zgodnie deklarują, że główny ciężar aktywności inwestycyjnej w najbliższych latach skoncentrowany będzie w Polsce (Domański, 2005: 193).

Ważnym kierunkiem inwestowania operatorów NKD będą również modernizacje istniejących obiektów handlowych. Mowa przede wszystkim o projektach proekologicznych, które będą podnosić efektywność energetyczną, optymalizować koszty i pozytywnie wpływać na środowisko. Najbardziej innowacyjnym przedsięwzięciem w tym zakresie jest odzyskiwanie ciepła z instalacji sprzętu chłodniczego, które wykorzystywane jest do ogrzewania wody sanitarnej obiektów handlowych (Kłosiewicz-Górecka, 2011: 139-140).

Coraz więcej operatorów handlu wielkopowierzchniowego decyduje się również na inwestycje w rozwój e-handlu. Rynek sklepów internetowych sprzedających artykuły żywnościowe w Polsce wyceniany jest obecnie na około $250 \mathrm{mln}$ zł (Kłosiewicz-Górecka, 2011: 141). W Internecie podjęło już sprzedaż wielu operatorów NKD (Feldy, Mróz, 2011: 214233).

Na zakończenie warto podkreślić nasilające się zjawisko (wykraczające poza standardowe strategie marketingowe) przejęć w NKD. Z polskiego rynku stopniowo wycofują się te firmy, które nie osiągnęły na nim silnej pozycji, umożliwiając dalszą konsolidację i umocnienie

${ }^{1}$ W Polsce powierzchnia hipermarketów znajdujących się na terenie centrów handlowych jest zdecydowanie większa niż we Francji. W projektach francuskich powierzchnia ta wynosi ok. $4500 \mathrm{~m} \mathrm{kw.,} \mathrm{natomiast} \mathrm{w} \mathrm{Polsce}$ osiąga nawet $14000 \mathrm{~m}$ kw.; za: www.apsys-international.fr.

${ }^{2}$ Rewitalizacja centrum miasta jest próbą jego ożywienia, wprowadzenia nowych funkcji w obszarach, których dotychczasowe funkcje wyczerpały się. Rewitalizacja jest procesem przemian przestrzennych, społecznych i ekonomicznych w zdegradowanych częściach miast, przyczyniającym się do poprawy jakości życia, przywrócenia ładu przestrzennego, a także do ożywienia gospodarczego; za: www.arl.pl (dostęp 2.03.2008) 
pozycji rynkowej czołowym graczom. Ten proces postępuje (choć szczególnie intensywny był w latach 1998-2007), zmienia się jedynie jego forma. Wzrasta bowiem zainteresowanie przedsiębiorstw handlowych przejmowaniem sieci małych i średniej wielkości sklepów zlokalizowanych blisko miejsca zamieszkania konsumentów, co w literaturze przedmiotu określa się jako nowy etap procesów koncentracji w handlu (Kłosiewicz-Górecka, 2011: 139).

Tab. 1. Przejęcia na polskim rynku w branży spożywczej w latach 1998-2007

\begin{tabular}{|c|c|c|c|c|c|}
\hline Rok & Firma & Sieć & Format & Liczba & Nabywca \\
\hline 1998 & Metro AG & Tip & $\mathrm{D}$ & 36 & Jeronimo Martins \\
\hline 2000 & GIB/Promodes & Globi & $\mathrm{S}$ & 26 & Carrefour \\
\hline 2001 & Rewe & Billa & $\mathrm{S}$ & 11 & Auchan \\
\hline 2002 & Dohle & Hit & $\mathrm{H}$ & 13 & Tesco \\
\hline 2002 & Jeronimo Martins & Jumbo & $\mathrm{H}$ & 5 & Ahold \\
\hline 2003 & Edeka & E-discount & $\mathrm{D}$ & 45 & Royal Markety \\
\hline 2003 & Ahold & Hypernova & $\mathrm{H}$ & 2 & Carrefour \\
\hline 2003 & Reitan & Rema 1000 & $\mathrm{~S}$ & $43 / 16$ & $\begin{array}{l}\text { DRD F.Em./ Jeronimo } \\
\text { Martins }\end{array}$ \\
\hline 2003 & DRD Ford Emporium & Rema 1000 & $\mathrm{~S}$ & 16 & Jeronimo Martins \\
\hline 2005 & Ahold & Hypernova & $\mathrm{H}$ & 2 & Carrefour \\
\hline 2005 & Ahold & Hypernova & $\mathrm{H}$ & 1 & Real \\
\hline 2005 & Julius Meinl & Julius Meinl & $\mathrm{S}$ & 9 & Tesco \\
\hline 2006 & Casino & Geant & $\mathrm{H}$ & 19 & Real \\
\hline 2006 & Casino & Lieder Price & $\mathrm{D}$ & 145 & Tesco \\
\hline 2006 & Ahold & Hypernova & $\mathrm{H}$ & 15 & Carrefour \\
\hline 2006 & Ahold & Albert & S & 179 & Carrefour \\
\hline 2007 & $\begin{array}{l}\text { LD Holding i Curylo- } \\
\text { Asterix (hurtownia) }\end{array}$ & eLDe & ss & 250 & Rabat Pomorze \\
\hline 2007 & Społem Tychy & Społem & S, ss & 36 & Emperia \\
\hline 2007 & Centrum & Centrum & $\mathrm{S}, \mathrm{ss}$ & 13 & Emperia \\
\hline 2007 & Maro-Markety & Maro-Markety & ss & 18 & Emperia \\
\hline 2007 & Euro Sklep & Euro Sklep & S, ss & 258 & Emperia \\
\hline 2007 & Polka & Polka & ss & 70 & Emperia \\
\hline 2007 & Zatoka & Zatoka & $\mathrm{S}$ & 14 & Emperia \\
\hline 2007 & Tengelmann & Plus Discount & $\mathrm{D}$ & 210 & Jeronimo Martins \\
\hline
\end{tabular}

Źródło: Kowalska, 2012: 13

Opisane wyżej strategie działania NKD mają kluczowe znaczenie dla perspektyw rozwoju handlu nowoczesnego w Polsce. Poszczególne praktyki wzajemnie się uzupełniają i zapewniają przewagę rynkową tej formy rynku nad handlem tradycyjnym. Siła NKD ma bowiem swoje źródło w skali działania, potencjale finansowym i stosowanych strategiach marketingowych - w akceptowanej ofercie rynkowej (Kłosiewicz-Górecka, 2007: 197). 


\section{WNIOSKI KOŃCOWE}

Opisane w artykule wybrane strategie NKD w istotny sposób kształtują standardy działania i warunki konkurencji na polskim rynku detalicznym. Nasilają presję konkurencją w handlu i coraz większym stopniu wymuszają działania dostosowawcze względem przedsiębiorstw, które decydują się na tym rynku pozostać.

Praktyki te przekładają się na siłę negocjacyjną sieci handlowych względem ich kontrahentów i większą lojalność klientów, powodują wyeliminowanie w wielu miejscach przewagi lokalizacyjnej tradycyjnego handlu nad handlem nowoczesnym (ze względu na rozwój nowoczesnych centrów handlowych blisko ścisłej tkanki miejskiej czy dalsze inwestycje w tzw. sklepy kompaktowe).

Skala i jakość omówionych działań handlu nowoczesnego wyznaczają dzisiaj pozycję przedsiębiorstwa na rynku i wydaje się, że w istotny sposób rzutować będzie na strukturę rynku detalicznego w przyszłości. Opisane strategie wymagają bowiem wysoce kapitałochłonnych inwestycji (np. w nowoczesne systemy informatyczne, rozwój bogatej oferty marki własnej). Świadczy to o tym, że najbardziej efektywne strategie marketingowe mogą rozwijać tylko największe i najsilniejsze finansowo sieci detaliczne. Szczególne znaczenie w tym zakresie odgrywa proces koncentracji w handlu detalicznym, który przez różnicowanie wielkości przedsiębiorstw zwiększa siłę rynkową i możliwości finansowe określonych podmiotów.

W tym kontekście kluczowe znaczenie dla polskiego handlu mają dzisiaj działania integracyjne (głównie franszyzowe), które pozwalają ograniczyć dystans, jaki dzieli tradycyjny i nowoczesny handel.

\section{Literatura}

AC Nielsen. (2007). Shopper Trends Pozyskano z: www. retailpoland.com

Domański, T. (2001). Strategie marketingowe dużch sieci handlowych. Warszawa-Lódź: Wydawnictwo Naukowe PWN.

Domański, T. (2005). Strategie rozwoju handlu. Warszawa: Wydawnictwo PWE.

Feldy, M., Mróz, B. (2011). Rozwój handlu internetowego w Polsce. W: U. Kłosiewicz-Górecka (red.), Handel wewnętrzny w Polsce 2006-2011. Warszawa: Instytut Badań Rynku, Konsumpcji i Koniunktur, 214-233.

Kłosiewicz-Górecka, U. (red.) (2007). Zagraniczne inwestycje w handlu na rynkach lokalnych. Warszawa: Wydawnictwo PWE.

Kłosiewicz-Górecka, U. (2011). Bezpośrednie inwestycje zagraniczne w sferze handlu zagranicznego w Polsce. W: Inwestycje zagraniczne w Polsce 2009-2011. Warszawa: Instytut Badań Rynku, Konsumpcji i Koniunktur, 126-143.

Kowalska, K. (2012), Rozwój polskich sieci detalicznych jako sposób ograniczania sity rynkowej międzynarodowych korporacji handlowych. Warszawa: Wydawnictwo Difin.

Krall, J. (2001). Silna marka. Istota i kreowanie. Warszawa: Wydawnictwo PWE. 
Kubacka, D. (2012). Klienci najczęściej robia zakupy w dyskontach Biedronka. Pozyskano z: www. retailpoland.com

Private labels get sophisticated (2009). Pozyskano z: www.retailpoland.com

Private labels in Poland: buying ad half price (2009). Pozyskano z: www.pmrpublications.com

Procesy konsolidacji i koncentracji w handlu, Handel. Pozyskano z: www.retailponad.com

Richardson, P.S., Dick, A.S., Jain, A.K. (1994). Extrinsic and Intrinsic Cue Effects on Perceptions of Store Brand Quality, Journal of Marketing, 58(4).

Twardzik, K. (2012). Produkty codziennego użytku sprawdzaja się jako marki własne. Pozyskano z: www.retailpoland.com

\section{Strony internetowe}

www.apsys-international.fr

www.arl.pl

www.pmrpublications.com

www.retailpoland.com

Katarzyna Kowalska, dr, Uniwersytet Pedagogiczny, Instytut Politologii, Katedra Ekonomii i Polityki Gospodarczej.

Zainteresowania naukowe autorki dotyczą: internacjonalizacji przedsiębiorstwa, społecznej odpowiedzialności międzynarodowych korporacji, koncentracji i dominacji w handlu, konkurencji w handlu.

Katarzyna Kowalska, $\mathrm{PhD}$, Pedagogical University of Cracow, Institute of Political Science, Department of Economics and Economic Policy.

Interests: enterprise internationalization, corporate social responsibility, concentration and domination in trade, competition in trade.

adres/address: Uniwersytet Pedagogiczny w Krakowie

Instytut Politologii, Katedra Ekonomii i Polityki Gospodarczej

ul. Podchorążych 2, 30-084 Kraków, Polska

e-mail:k.kowalska04@wp.pl 